African Crop Science Journal by African Crop Science Society is licensed under a Creative Commons Attribution 3.0 Uganda License. Based on a work at www.ajol.info/ and www.bioline.org.br/cs DOI: https://dx.doi.org/10.4314/acsj.v28i1.2S

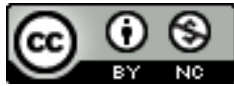

\title{
OPTIMISATION OF OVEN-DRYING OF BAOBAB LEAVES USING A CENTRAL COMPOSITE DESIGN
}

\author{
A.M. GBAGUIDI ${ }^{1,2}$, F.J. CHADARE ${ }^{1,2}$, V.K. SALAKO ${ }^{3}$, Y.O.V. IDOHOU ${ }^{2}$ \\ and A.E. ASSOGBADJO ${ }^{4}$ \\ ${ }^{1}$ Laboratoire de Sciences et Technologie des Aliments et Bioressources et de Nutrition Humaine, \\ Université Nationale d'Agriculture (LaSTAB-NH/UNA), Sakété, Bénin \\ ${ }^{2}$ Laboratoire de Sciences des Aliments, Ecole de Nutrition et des Sciences et Technologies des \\ Aliments, Faculté des Sciences Agronomiques, Université d'Abomey-Calavi (ENSTA/FSA/UAC), \\ Abomey-Calavi, Bénin \\ ${ }^{3}$ Laboratoire de Biomathématiques et d'Estimations Forestières, Faculté des Sciences \\ Agronomiques, Université d'Abomey-Calavi (LABEF/FSA/UAC), Abomey-Calavi, Bénin \\ ${ }^{4}$ Laboratoire d'Ecologie Appliquée, Faculté des Sciences Agronomiques, Université d'Abomey- \\ Calavi (LABEF/FSA/UAC), Abomey-Calavi, Bénin \\ Corresponding author: fchadare@gmail.com
}

\begin{abstract}
Baobab (Adansonia digitata) leaves represent a key nutritional resource; although their consumption is apparently restricted to local communities, mainly as a sticky sauce, cosmetics and a variety of purposes. Ready-to-use powder of oven-dried baobab leaves can improve the availability of the product on markets, and hence its utilisation and shelf life. This study was carried out to optimise the oven-drying temperature and duration for the best conservation of baobab leaf powder and its sustainable availability for multipurpose uses. Different combinations of values of temperature and drying duration were generated, using a central composite design, in response surface methodology framework. Findings showed that dry matter, hue, chroma and lightness were significantly influenced by oven-drying temperature and duration; while the least gelation concentration was significantly influenced by the temperature. Based on leaf dry matter, hue and chroma models, the optimal oven drying conditions for baobab leaves for good preservation leading to human consumption and other purposes are set at $45^{\circ} \mathrm{C}$ for 23.5 hours.
\end{abstract}

Key Words: Adansonia digitata, colour, dry matter

\section{RÉSUMÉ}

Les feuilles de baobab (Adansonia digitata) représentent une resource nutritionnelle principal; bien que leur consommation soit apparemment limitée aux communautés locales, principalement sous forme de sauce collante, de cosmétiques et à diverses fins. La poudre de feuilles de baobab qui est séchée dans le four et qui est prête à être utilisée peut améliorer la disponibilité du produit sur les marchés, son 
utilisation et sa durée de conservation. Cette étude a été réalisée afin d'optimiser la température et la durée de séchage dans le four pour la meilleure conservation de la poudre de feuilles de baobab et sa disponibilité durable pour des usages polyvalents. Les différentes combinaisons de valeurs de température et de durée de séchage ont été générées, en utilisant une conception composite centrale, dans le cadre de la méthodologie de surface de réponse. Les résultats ont montré que la matière sèche, la teinte, la chrominance et la légèreté étaient significativement influencées par la température et la durée de séchage dans le four four; tandis que la moindre concentration de gélification était significativement influencée par la température. En se basant sur des modèles de matière sèche, de teinte et de chrominance des feuilles, les conditions optimales de séchage au four des feuilles de baobab pour une bonne conservation conduisant à la consommation humaine et à d'autres fins sont fixées à $45^{\circ} \mathrm{C}$ pendant 23,5 heures.

Mots Clés: Adansonia digitata, couleur, matière sèche

\section{INTRODUCTION}

One of the major challenges to ensure sustainable food availability in many developing countries is the lack of adapted food preservation techniques. Drying is one of the traditional methods, mostly used in food conservation, including the one of baobab (Adansonia digitata) leaves. Different types of drying technics are used in the food industry; namely, thermal drying, chemical drying and the special (Freeze, $\mathrm{CO}_{2}$, Microwave) drying (Babu et al., 2018). Thermal drying can be done by natural convection or forced convection.

The natural convection technics are the open-sun drying, the shade drying and the wind drying. Consequently, the efficiency of the natural convection depends on the atmospheric conditions. The forced convection technics include the cabinet tray (bed) drying (fixed bed drying, oven drying, solar drying, heat pump drying, ECP drying, fluidised bed drying, hybrid drying), and the conveyor belt drying. Compared to the natural convection, the forced convection offers a better control of the drying conditions (droppings of birds and insects, dust and fungi). The chemical drying technics used for leaves include the Glycerin drying, the Silica sand drying and the calcium chloride drying (Babu et al., 2018).

Usually, for thermal drying, the lower the drying temperature, the longer the drying duration tends to be (Babu et al., 2018). The lower the relative humidity, the shorter the drying duration tends to last. Babu et al. (2018) recommend a drying temperature range of 40 to $60^{\circ} \mathrm{C}$ for leaf physical quality preservation. Above this temperature, the colour and the texture of the leaves tends to deteriorate. Within this range of temperatures, different drying durations were documented. Optimum sets of oven drying conditions in terms of temperature-duration combinations have been documented as $20 \mathrm{hr}$ at $50^{\circ} \mathrm{C}$ and $15 \mathrm{hr}$ at $70^{\circ} \mathrm{C}$ for Thymisdaenensis subsp. daenensis Celak leaves (Rahimmalek and Goli, 2013); and 9, 8 and $7 \mathrm{hr}$, respectively, at 40, 55 and 70 ${ }^{\circ} \mathrm{C}$ for Echinaceae purpurea leaves (Lin et al., 2011).

High drying temperatures reduce the length of drying, but often decreases the nutritional and nutraceutical quality (Alara et al., 2019), and colour (Babu et al., 2018) of the product. Conversely, low drying temperatures reportedly conserve some of the natural nutritional components, but with the consequence that drying duration will be longer (Babu et al., 2018). Therefore, finding the drying temperature and duration that optimise drying, while conserving nutritive and nutraceutical components, as well as organoleptic characteristics, on the other hand, and the volatile compounds which represent the most affected in foods drying, is essential in food industry. In particular, the preservation of the colour, which influences the merchantability of the final product, is an 
essential goal of drying for spices and others products (Rahimmalek and Goli, 2013).

It has been demonstrated that baobab pulp and leaves are rich in nutrients and exhibit high antioxidant activity (Braca et al., 2018). With the growing interest in baobab derived products, it is essential to improve their quality and storability in order to add value and for multiple uses, including human consumption. This study was carried out to optimise the oven-drying temperature and duration to produce good quality baobab leaf powder with good conservation.

\section{MATERIALS AND METHODS}

The experimental design used was a response surface methodology (RSM), specifically the Central Composite Design (CCD) with two factors, namely the drying temperature and drying duration (Table 1). Minimum and maximum values applied for drying temperature were 47 and $63{ }^{\circ} \mathrm{C}$, and 9 and 21 $\mathrm{hr}$ for drying duration. The design was generated with Minitab 19 software. The central point $\left(55^{\circ} \mathrm{C} ; 15 \mathrm{hr}\right)$ was repeated two times. In total, eleven combinations were generated as in Table 1.
Fresh young baobab leaves (14 - 21 days) were harvested in the experimental site of the "Faculté des Sciences Agronomiques" of the University of Abomey-Calavi, in Benin. At the laboratory, the leaves were sorted to discard yellow leaves and impurities, thoroughly cleaned with tap water and drained for 15 minutes.

Approximately $20 \mathrm{~g}$ of the drained baobab leaves were spread on a plate of a hot-air drying oven (VENTI-Line VWR), at a constant air velocity $\left(6 \mathrm{~m} \cdot \mathrm{s}^{-1}\right)$. The specific temperature and duration of drying were calibrated for each combination (Table 1). The dried leaves were powdered using an IKA grinder analysis (Model A11B) and the leaf powder was used to determine dry matter, colour, and the least gelation concentration.

The colour of baobab leaf powder was assessed in triplicate, using the chromameter "CR410 Konica Minolta" (Minolta, 2003), and expressed through the parameters $L^{*}, a^{*}, b^{*}$. The chroma $\left[\mathrm{C}^{*}=\left(\mathrm{a}^{* 2}+\mathrm{b}^{* 2}\right)^{1 / 2}\right]$ and hue $\left[\mathrm{H}^{*}=\right.$ $\left.\tan ^{-1}\left(b^{*} / a^{*}\right)\right]$ were calculated to name the colour range of the dry leaf powder. The colour expressed by the hue was qualified as "dull" (low chroma values) or "vivid" (high chroma values). The lightness varies from 0 (Black)

TABLE 1. Treatments for the baobab leaves oven drying optimisation experiment

\begin{tabular}{|c|c|c|c|c|c|}
\hline \multirow[t]{2}{*}{$\mathrm{N}^{\circ}$} & \multirow[t]{2}{*}{ Type of points } & \multicolumn{2}{|c|}{ Variables codes } & \multicolumn{2}{|c|}{ Variables values } \\
\hline & & Temperature $\left({ }^{\circ} \mathrm{C}\right)$ & Duration (hr) & Temperature $\left({ }^{\circ} \mathrm{C}\right)$ & Duration (hr) \\
\hline 1 & Central & 0 & 0 & 55 & 15 \\
\hline 2 & Central & 0 & 0 & 55 & 15 \\
\hline 3 & Central & 0 & 0 & 55 & 15 \\
\hline 4 & Axial & 1 & 1 & 63 & 21 \\
\hline 5 & Axial & 1 & -1 & 63 & 9 \\
\hline 6 & Axial & -1 & 1 & 47 & 21 \\
\hline 7 & Axial & -1 & -1 & 47 & 9 \\
\hline 8 & Cubic & 1.4142 & 0 & 66.5 & 15 \\
\hline 9 & Cubic & -1.4142 & 0 & 44 & 15 \\
\hline 10 & Cubic & 0 & 1.4142 & 55 & 23.5 \\
\hline 11 & Cubic & 0 & -1.4142 & 55 & 6.5 \\
\hline
\end{tabular}


to 100 (White); the grey scale corresponds to a value of 50 for the lightness.

Dry matter was determined in duplicates, according to AOAC 1995 (AOAC, 1995), in a Heraeus oven. The least gelation concentration was determined by the method described by Sathe and Salunkhe (1981), with minor modification. That is, $10 \mathrm{ml}$ of baobab leaf powder suspension were prepared at concentrations ranging from 2 to $20 \%$ (w/v), in test tubes. The tubes were placed in boiling water for one hour, cooled under tap water and kept in a refrigerator at $4{ }^{\circ} \mathrm{C}$ for one hour. The least gelation concentration was determined as the concentration where the sample did not slip when tubes were inverted, and expressed as a function of the dry matter.

Data were analysed using Minitab 19.0 software, and a second-order polynomial equation was established to assess the linear, quadratic and interaction effects of drying temperature and duration on all response variables. The equation for a response variable Y, was as follow:

$Y=a_{0}+a_{1} \cdot T+a_{2} \cdot T^{2}+b_{1} \cdot t+b_{2} \cdot t^{2}+c . T . t$ Equation 1

Where:

$\mathrm{Y}=$ is the response variable, $\mathrm{a}_{0}, \mathrm{a}_{1}, \mathrm{a}_{2}, \mathrm{~b}_{1}, \mathrm{~b}_{2}$, c, are the model coefficients;

$\mathrm{T}=$ the drying temperature; and

$\mathrm{t}=$ the drying duration.

For each response variable, the goodness of fit of the model fitted was examined with the lack-of-fit-test.

For this test, a P-value greater than 0.05 indicates good fit, and poor fit otherwise. The global significance of the model was tested with an analysis of variance; while the significance of each term of the model was examined with the Student t-test (Lenth, 2009).

Optimisation of drying process was done using the overall desirability function (D) (Costa et al., 2011). This function is the geometric mean of individual response desirabilities (Costa et al., 2011). Only individual models with a good fit were used in the optimisation.

$D=\prod_{i=1}^{n} d_{i}$ Equation 2

Where:

$\mathrm{D}=$ the overall desirability;

$\mathrm{n}=$ the number of response variables; and

$\mathrm{d}=$ the individual desirability of each response variables.

The optimum was found by setting the target dry matter to $92 \%$ as recommended by the Codex Alimentarius (Codex, 2017) for dried thyme (CX/S. 2017. 328-2017), in the absence of standards regarding dried baobab leaves, and by maximising the hue and the chroma, using the software Minitab 19.

\section{RESULTS AND DISCUSSION}

Values of dry matter, least gelation concentration, hue, chroma and lightness were, respectively, $93.4 \pm 1.8 \mathrm{~g} .100 \mathrm{~g}^{-1}, 7.2 \pm 1.3$ g. $100 \mathrm{~mL}^{-1} \mathrm{dw}, 109.6 \pm 6.1^{\circ}, 14.0 \pm 1.9$ and $51.8 \pm 5.8$ (Table 2). The dry leaf powder was duller (Minolta, 2003) than the fresh baobab leaves, based on the chroma values; and their hue values and lightness ranged from yellow to green colour, and in greyish zone, respectively (Table 2 ). The lower the dry matter of the analysed baobab leaf, the lower is the associated lightness. This observed variation of the lightness (Table 2) was consistent with the findings of Soomro et al. (2020), who reported that the lightness of paddy was low at low dry matter. Moreover, the correlation coefficient between dry matter and the lightness was 0.614 , indicating that dry matter could be used as a proxy for the variability of the lightness. Similarly, the lightness value could be used as a rapid prediction tool of the dry matter 
TABLE 2. Variation of baobab leaf dry matter, least gelation concentration and colour for all experimental points (combinations of values of drying temperature and duration)

\begin{tabular}{|c|c|c|c|c|c|c|c|c|}
\hline \multirow[t]{2}{*}{ Leaves state } & \multicolumn{4}{|c|}{ Independent variables } & \multicolumn{4}{|c|}{ Responses variables } \\
\hline & $\begin{array}{c}\text { Temperature } \\
\left({ }^{\circ} \mathrm{C}\right)\end{array}$ & $\begin{array}{l}\text { Duration } \\
\text { (hr) }\end{array}$ & $\begin{array}{l}\text { Dry matter } \\
\left(\mathrm{g} 100 \mathrm{~g}^{-1}\right)\end{array}$ & $\begin{array}{l}\text { Lightness } \\
\left(\mathrm{L}^{*}\right)\end{array}$ & Hue (in ${ }^{\circ}$ ) & Chroma & $\begin{array}{c}\text { LGC } \\
\left(\mathrm{g} 100 \mathrm{ml}^{-1} \mathrm{dw}\right)\end{array}$ & “E \\
\hline \multirow[t]{11}{*}{ Dried leaf powder } & 44 & 15 & $90.6 \pm 0.1$ & $52.4 \pm 0.3$ & $116.9 \pm 0$ & $12.5 \pm 0.2$ & $6.6 \pm 0$ & $25.2 \pm 0.2$ \\
\hline & 47 & 9 & $90 \pm 0.1$ & $34.8 \pm 0$ & $112.4 \pm 0.1$ & $11.7 \pm 0$ & $6.7 \pm 0$ & $11.8 \pm 0$ \\
\hline & 47 & 21 & $92.8 \pm 0.1$ & $54.4 \pm 0.2$ & $115.1 \pm 0.1$ & $14.2 \pm 0.1$ & $6.5 \pm 0$ & $25.9 \pm 0.3$ \\
\hline & 55 & 7 & $92.8 \pm 0.2$ & $54.7 \pm 0$ & $111.8 \pm 0.1$ & $16.3 \pm 0.2$ & $6.5 \pm 0$ & $26.1 \pm 0$ \\
\hline & 55 & 23 & $93.1 \pm 0.1$ & $56.3 \pm 0.3$ & $117.6 \pm 0.2$ & $17.8 \pm 0.2$ & $6.4 \pm 0$ & $27.7 \pm 0.4$ \\
\hline & 55 & 15 & $94.7 \pm 0.6$ & $52.6 \pm 1$ & $109.8 \pm 5.5$ & $13.9 \pm 0.8$ & $6.3 \pm 0$ & $25.3 \pm 1.5$ \\
\hline & 55 & 15 & $94.2 \pm 0.1$ & $53 \pm 1.1$ & $110.3 \pm 4.8$ & $13.4 \pm 0.8$ & $6.4 \pm 0$ & $25.7 \pm 1.3$ \\
\hline & 55 & 15 & $94.4 \pm 0.4$ & $54.1 \pm 0.6$ & $106.5 \pm 0.7$ & $14.5 \pm 0.2$ & $6.4 \pm 0$ & $26.9 \pm 0.3$ \\
\hline & 63 & 9 & $95.8 \pm 0.6$ & $56 \pm 0.1$ & $105.4 \pm 0.4$ & $15.5 \pm 0.2$ & $10.4 \pm 0.1$ & $28.7 \pm 0.2$ \\
\hline & 63 & 21 & $94.7 \pm 0.2$ & $52.4 \pm 0.1$ & $100.1 \pm 0$ & $12.3 \pm 0.1$ & $8.5 \pm 0$ & $28.5 \pm 0.2$ \\
\hline & 66 & 15 & $94.1 \pm 0.1$ & $49.5 \pm 0$ & $100.2 \pm 0.1$ & $12.2 \pm 0.1$ & $8.5 \pm 0$ & $26.1 \pm 0$ \\
\hline Mean values & & & $93.4 \pm 1.8$ & $51.8 \pm 5.8$ & $109.6 \pm 6.1$ & $14 \pm 1.9$ & $7.2 \pm 1.3$ & $25.3 \pm 4.5$ \\
\hline Fresh leaf & & - & $27.6 \pm 0.1$ & $29.3 \pm 1.6$ & $113.6 \pm 1.2$ & $22.1 \pm 1.7$ & - & $40.6 \pm 2.0$ \\
\hline
\end{tabular}


Dry matter. The model describing the variability of dry matter $\left(\mathrm{Y}_{\mathrm{DM}}\right)$ during the ovendrying process was globally significant $(\mathrm{P}<0.001)$ (Table 3). The probability of the lack-of-fit test (Table 3 ) also indicated that the model fitted well to the data $(\mathrm{P}>0.05)$. The adjusted and predicted $\mathrm{r}^{2}$ were all very high $(>80 \%$, Table 3$)$, indicating a very good explanatory and predictive power of the obtained model. The model was:

$$
\begin{aligned}
Y_{D M}= & 94.46+1.59 . T-0.89 . T^{2}+0.26 . t- \\
& 0.58 . t^{2}-1.00 . T . t
\end{aligned}
$$

The significant terms were the linear and quadratic effects of temperature, the interaction of both factors' linear effects and the quadratic effect of the duration $(\mathrm{P}<0.05)$ (Table 3, Fig. 1). The terms of the model with significant negative effects, i.e. inducing a decrease in DM, were the quadratic effect of the temperature, the quadratic effect of duration, and the interaction of both factors. Conversely, the only term with significant positive effect, i.e. inducing an increase in DM, was the linear effect of temperature. This suggests that holding the duration constant, the dry matter will increase as the temperature increases, to reach a maximum value; after which it starts decreasing, especially for higher values of temperature. Indeed, for extremely high temperatures, it is likely that free water removal is achieved, which should be followed by difficult removal of bound water or even burning, which will affect dry matter content. Such relationships are consistent with findings of Seremet et al. (2016).

Figure 1 shows the response surface plot of dry matter, in responsive to drying temperature and duration, based on the above model and confirm the above trends.

Least gelation concentration. Concerning the least gelation concentration, the quadratic model was also globally significant $(\mathrm{P}<0.001)$. The adjusted and predicted $r$-square were all high $(>50 \%)$, indicating a good explanatory and predictive power of the obtained model (Table 3). The model was:

$$
\begin{aligned}
Y_{L G C}= & 6.35+1.05 . T+0.85 . T^{2}-0.28 . t+ \\
& 0.30 . t^{2}-0.45 . T . t
\end{aligned}
$$

The significant terms were the linear and quadratic effects of temperature $(\mathrm{P}<0.005)$ and both had positive effects i.e. inducing an increase in LGC. The significance of the quadratic term of the temperature, indicates a rapid increase of LGC for high temperatures, holding the duration constant. This implies that it is necessary to keep the temperature below a limit to keep the LGC low, which is necessary to maintain the gelling properties of the leaf powder.

Figure 2 shows the response surface plot of LGC in relationship to drying temperature and duration based on the above model. The analysis of the surface plot revealed that LGC was significantly constant from 44 to $55^{\circ} \mathrm{C}$, and increased above the temperatures of 55 ${ }^{\circ} \mathrm{C}$, indicated that the drying temperature should be below $55{ }^{\circ} \mathrm{C}$ to allow the conservation of the LGC at a low value, hence keeping active the gelling properties of baobab leaf powder. Baobab leaves should then be dried at a temperature lower than $55^{\circ} \mathrm{C}$.

The low values of the adjusted $\mathrm{r}^{2}$ coefficient for the LGC could be related to the origin of the gel formation. Indeed, gelation is the combination of denaturated protein chains into a three dimensional network with immobilised or trapped water in it, and results in the formation of rigid gel structure (Mishyna et al., 2019); measured through the least gelation concentration. This gelling property can be affected by the $\mathrm{pH}$ of the leaf solution, the pectin concentration, the presence of bivalent as calcium and its concentration (Han et al., 2017; Yuliarti et al., 2017). Baobab leaves contain $12.8 \mathrm{~g} .100 \mathrm{~g}^{-1} \mathrm{dw}$ of proteins, and $1582 \mathrm{mg} .100 \mathrm{~g} \mathrm{dw}^{-1}$ of calcium (Rashford, 2018). The gelling property observed through the least gelation concentration data collected from the present study, can be linked to the 
TABLE 3. Analysis of Variance of dry matter, least gelation concentration and colour attributes

\begin{tabular}{|c|c|c|c|c|c|c|c|c|c|c|c|}
\hline \multirow[t]{2}{*}{ Source } & \multirow[t]{2}{*}{$\mathrm{df}$} & \multicolumn{2}{|c|}{$\begin{array}{l}\text { Least gelation } \\
\text { concentration }\end{array}$} & \multicolumn{2}{|c|}{ Dry matter } & \multicolumn{2}{|c|}{ Hue } & \multicolumn{2}{|c|}{ Chroma } & \multicolumn{2}{|c|}{ Lightness } \\
\hline & & $\mathrm{p}$ & Coef. & $\mathrm{p}$ & Coef. & $\mathrm{p}$ & Coef. & $\mathrm{p}$ & Coef. & $\mathrm{p}$ & Coef. \\
\hline Model & 6 & $<0.001$ & & $<0.001$ & & $<0.001$ & & $<0.001$ & & 0.007 & \\
\hline Blocks & 1 & 0.968 & & 0.565 & & 0.412 & & 0.733 & & 0.769 & \\
\hline Intercept & & $<0.001$ & 6.35 & & 94.42 & 0.000 & 108.86 & $<0.001$ & 13.93 & $<0.001$ & 53.23 \\
\hline Linear & 2 & $<0.001$ & & $<0.001$ & & 0.000 & & 0.555 & & 0.034 & \\
\hline Temperature & 1 & $<0.001$ & 1.05 & $<0.001$ & 1.59 & 0.000 & -5.69 & 0.470 & 0.17 & 0.081 & 1.89 \\
\hline Duration & 1 & 0.139 & -0.28 & 0.094 & 0.26 & 0.382 & 0.69 & 0.424 & 0.19 & 0.040 & 2.28 \\
\hline Square & 2 & 0.004 & & $<0.001$ & & 0.031 & & $<0.001$ & & 0.205 & \\
\hline Temperature $\times$ temperature & 1 & 0.001 & 0.85 & $<0.001$ & -0.89 & 0.284 & -1.01 & $<0.001$ & -1.11 & 0.102 & -2.10 \\
\hline Duration $\times$ duration & 1 & 0.175 & 0.30 & 0.004 & -0.58 & 0.036 & 2.09 & $<0.001$ & 1.25 & 0.878 & 0.19 \\
\hline Interaction & 1 & 0.096 & & $<0.001$ & & 0.083 & & $<0.001$ & & 0.001 & \\
\hline Temperature $\times$ duration & 1 & 0.096 & -0.45 & $<0.001$ & -1.00 & 0.083 & -2.00 & $<0.001$ & -1.42 & 0.001 & -5.79 \\
\hline Error & 15 & & & & & & & & & & \\
\hline Lack-of-Fit & 11 & $<0.001$ & & 0.190 & & 0.607 & & 0.203 & & 0.001 & \\
\hline Total & 21 & & & & & & & & & & \\
\hline $\mathrm{R}^{2} \operatorname{adj}(\%)$ & & & 70.9 & & 89.1 & & 75.2 & & 76.7 & & 51.8 \\
\hline $\mathrm{R}^{2}$ pred. (\%) & & & 49.6 & & 82.0 & & 63.0 & & 62.2 & & 16.9 \\
\hline
\end{tabular}

The probabilities in bold indicate the significance of the source. Coef. $=$ Coefficient 


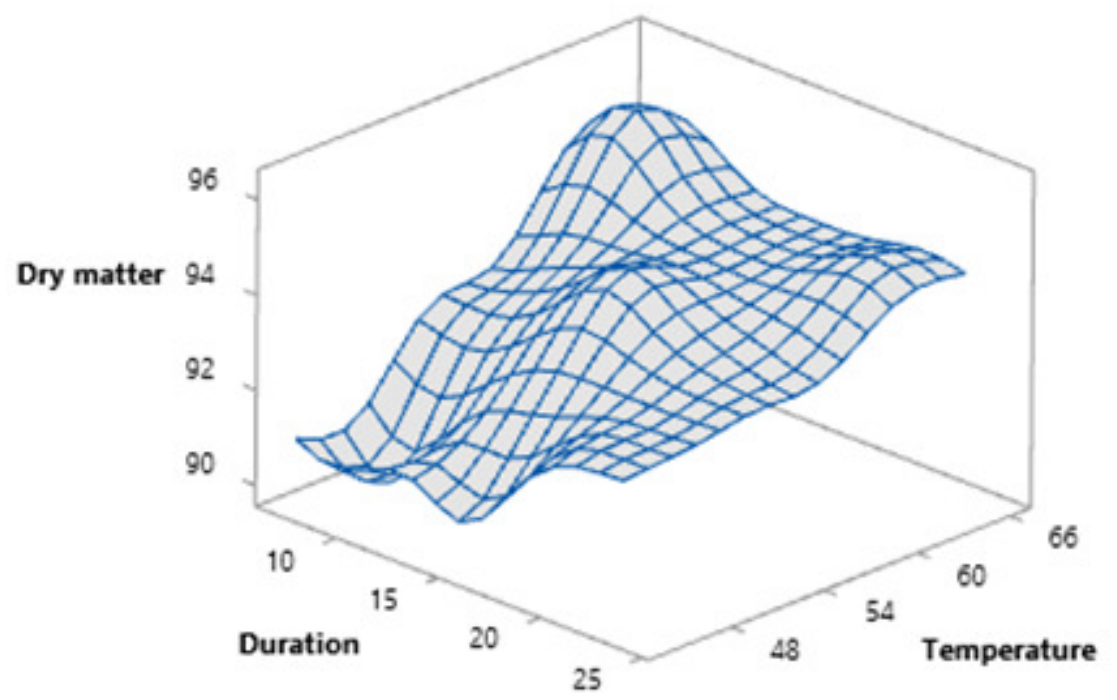

Figure 1. Response surface plot of baobab leaf dry matter as a function of drying temperature and duration.

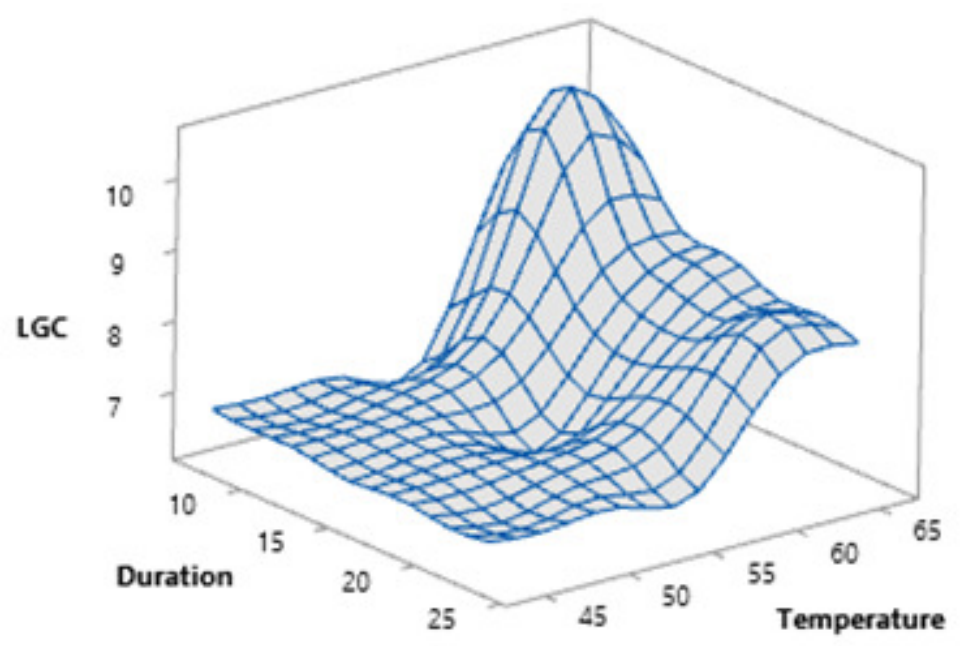

Figure 2. Surface plot of least gelation concentration as a function of baobab leaf drying temperature and duration.

baobab pectin associated to calcium content, but also related to the protein content in the baobab leaves. A total of $71.9 \%\left(\mathrm{r}^{2}{ }_{\text {adj }}\right)$ of the variability of the least gelation concentration was linked to the temperature, but the remaining variability $(29.1 \%)$ could be linked to the variabilities of the pectin content, the bivalents content and the protein content. A study on the gelling capacity of baobab leaves powder should be further investigated.

Baobab leaves powder colour. Colour variability was expressed through the hue $\left(\mathrm{H}^{*}\right)$, the lightness $\left(\mathrm{L}^{*}\right)$ and the chroma $\left(\mathrm{C}^{*}\right)$ 
variabilities models; which based on the variability of lightness $\left(\mathrm{Y}_{\mathrm{L}^{*}}\right)$ during the ovendrying process were globally significant $(\mathrm{P}<$ $0.05)$. The probability of the lack-of-fit test (Table 3) indicated that the model fitted well to hue and chroma, but not to lightness, even after a box-cox transformation (Table 3). The adjusted and predicted $\mathrm{r}^{2}$ for lightness were 51.84 and $16.89 \%$, respectively (Table 3 ), indicating an acceptable explanatory power, but a low predictive power of the obtained model represented by:

$Y_{L^{*}}=53.23+1.89 . T-2.10 . T^{2}+2.28 . t+0.19 t^{2}$ $-5.79 . T . t$

The significant terms were the linear effects of duration and interaction of both factors $(\mathrm{P}<0.05)$. The linear effect of drying duration had a positive effect, while the interaction effect of drying duration and temperature was negative. This negative effect of the interaction of both factors indicates opposing effects of both factors on lightness, i.e. increasing temperature and duration decreased lightness.

Figure 3 shows the response surface plot of lightness in relation to drying temperature and duration based on the above model. Drying at higher temperatures $\left(62-66^{\circ} \mathrm{C}\right)$ for more than 10-15 hours, tended to decrease the lightness. Indeed, high drying temperatures lead to the reduction in lightness (Pathare $e t$ al., 2013; Rahimmalek and Goli, 2013).

As for the chroma, the quadratic model $\left(\mathrm{Y}_{\mathrm{C}^{*}}\right)$ was equally globally significant $(\mathrm{P}<$ $0.001)$. The adjusted and predicted $\mathrm{r}^{2}$ values were all high (> 60\%, Table 3 ), indicating a good explanatory and predictive power of the obtained model. The model was as follows:

$$
\begin{aligned}
Y_{C^{*}}= & 13.93+0.17 . T+0.19 . t-1.11 . T^{2}+ \\
& 1.25 . t^{2}-1.42 . T . t
\end{aligned}
$$

The significant terms were the quadratic effects, and the interaction of the linear effects of both factors $(\mathrm{P}<0.001)$. The quadratic effect of the temperature, and the interaction effect of both factors were negative. Conversely, the quadratic effect of duration was positive. Consequently, the effect of both factors was not in the same direction. Drying conditions should preserve the colour of leaves according to the Codex Alimentarius (Codex, 2017). Therefore, the dried baobab leaves should have chroma values closed to that of the fresh leaves $\left(C^{*}=22.1\right)$.

Figure 4 shows the response surface plot of chroma in relation to drying temperature and duration based on the above model; and confirm the above trends. The longer the

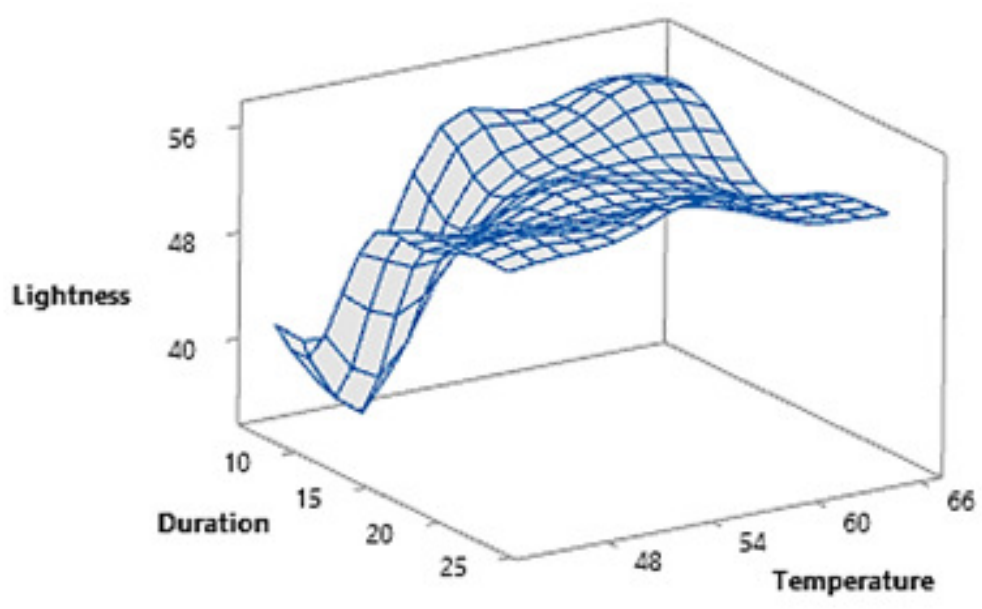

Figure 3. Surface plot of lightness as a function of baobab leaf drying temperature and duration. 


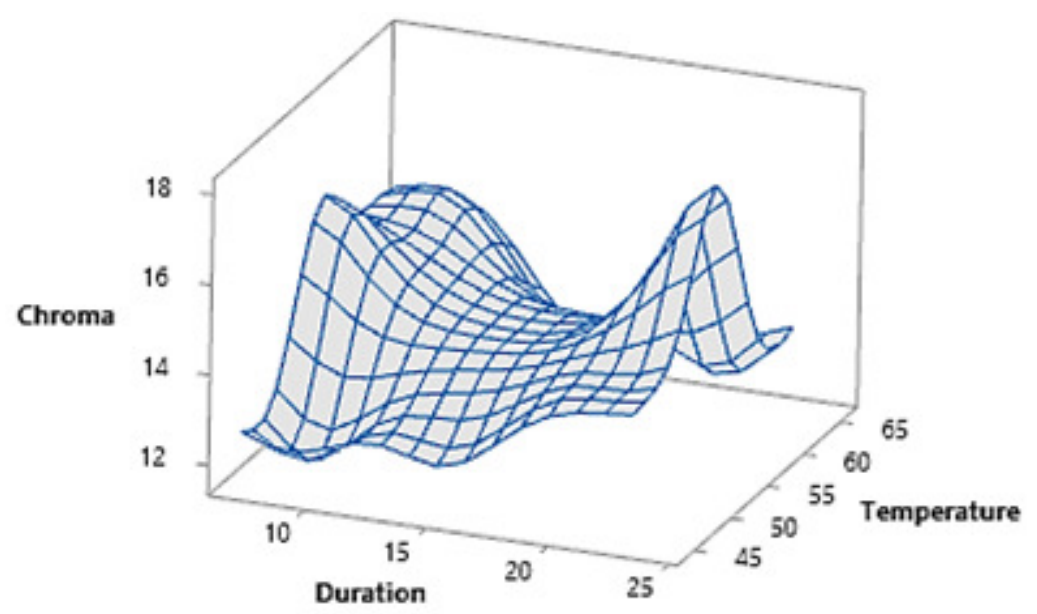

Figure 4. Surface plot of chromas a function of baobab leaf drying temperature and duration.

drying duration, the better the dried baobab leaves will have a vivid colour, attractive for traders and customers. Drying for long duration (20 to 24 hours) is, therefore, optimal for baobab leaves drying for chroma preservation.

With regard to the hue, the quadratic model $\left(\mathrm{Y}_{\mathrm{H}^{*}}\right)$ was also globally significant $(\mathrm{P}<0.001)$. The adjusted and predicted $r$-square were all high $(>60 \%)$, indicating a good explanatory and predictive power of the obtained model (Table 3). The model was as follows:

$$
\begin{aligned}
Y_{H^{*}}= & 108.86-5.69 . T+0.69 . t-1.01 . T^{2}+ \\
& \text { 2.09. } \\
& 2.00 . T . t
\end{aligned}
$$

The significant terms $(\mathrm{P}<0.05)$ were the linear effect of temperature and quadratic effect of duration; the first hada negative effect, and the second, a positive one. When the duration was increased, the hue also increased; and conversely the hue decreased with the increasing of temperature. Long drying durations led to dry leaves with hue close to the fresh leaves' hue.

Figure 5 shows the response surface plot of the hue in relation to drying temperature and duration based on the above model. The analysis of the surface plot revealed that the hue was higher at lower temperatures (45 -
$50{ }^{\circ} \mathrm{C}$ ). At these low temperatures, the hue variation was low, irrespective of the drying duration. Therefore, oven-drying at temperatures between $45-50{ }^{\circ} \mathrm{C}$ preserves the hue of the dry leaf powder as close as possible to that of fresh leaves.

Optimisation of the baobab leaves drying. Optimisation was performed on dry matter, hue and chroma, because the models had good fit for these three variables. Interestingly, these three variables had significant correlations with other response variables not considered in the optimisation. For example, Pearson pairwise correlation among response variables revealed a significant positive correlation between lightness and chroma $\left(\mathrm{r}^{2}=0.634, \mathrm{P}=0.002\right)$, and a significant negative correlation between least gelation concentration and hue $\left(r^{2}=-\right.$ 0.630, $\mathrm{P}=0.002$ ).

According to Codex standards (Codex, 2017) on dehydrated vegetable, the optimisation targeted dry matter at $92 \%$ and maximise the hue and the chroma. The optimal conditions for baobab leaves drying, with a composite desirability of $95.80 \%$, were: drying temperature of $45^{\circ} \mathrm{C}\left(44.83{ }^{\circ} \mathrm{C}\right)$ for 23.5 (23.4852) hours as drying duration. Dry leaf powder obtained with this drying duration and temperature had the following characteristics: 


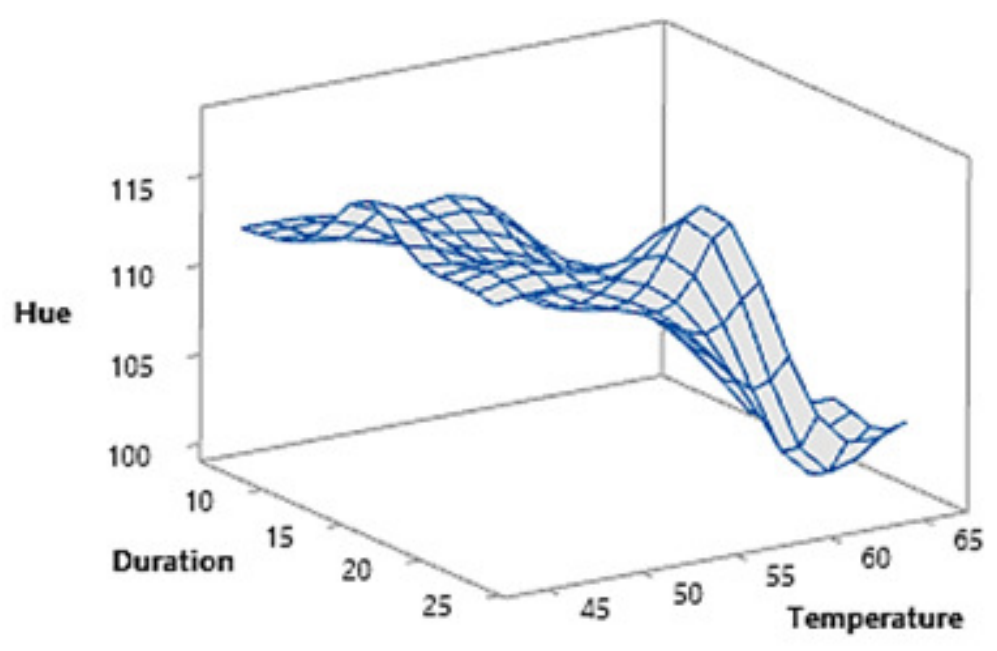

Figure 5. Surface plot of hue as a function of baobab leaf drying temperature and duration.

$92.01 \mathrm{~g} .100 \mathrm{~g}^{-1} \mathrm{dw}$ of dry matter, $123.20^{\circ}$ of hue value and 17.23 of chroma value. Such a characteristic of the dry matter is in line with the Codex Alimentarius Standards (Codex CX/ S. 2017. 328-2017). The values obtained for Hue and Chroma of dry leaf powder obtained from optimal conditions are close to the ones of baobab fresh leaves which have hue $=113.6$ and chroma $=22.1$.

\section{CONCLUSION}

The optimal drying conditions of baobab leaves are defined at $45{ }^{\circ} \mathrm{C}$ for 23.5 hours on the basis of dry matter, hue and chroma variability models during the oven drying of the fresh leaves. Further research should focus firstly on the application of these optimal baobab leaves drying conditions in solar dryers which use natural energy for drying; secondly on the modelling of chromatic parameters in baobab leaves drying; and thirdly on the development of a food derived from this dry leaf powder for promoting a better health for consumers.

\section{ACKNOWLEDGEMENT}

The authors are grateful to the Mastercard Foundation and Regional Universities Forum for Capacity Building in Agriculture
(RUFORUM) for funding research and publication cost through the Transforming African Agricultural Universities to meaningfully contribute to Africa's growth and development (TAGDev) Program.

\section{REFERENCES}

Alara, O.R., Abdurahman, N.H., Abdul Mudalip, S.K. and Olalere, O.A. 2019. Effect of drying methods on the free radicals scavenging activity of Vernonia amygdalina growing in Malaysia. Journal of King Saud University - Science 31(4):495-499.

AOAC. 1995. Official methods of analysis. $16^{\text {th }}$ edition. Association of official analytical chemists. Washington DC, USA.

Babu, A.K., Kumaresan, G., Antony Aroul Raja, V. and Velraj, R. 2018. Review of leaf drying: Mechanism and influencing parameters, drying methods, nutrient preservation, and mathematical models. Renewable and Sustainable Energy Reviews 90:536-556.

Codex CX/S. 2017. 328-2017.Codex Alimentarius. Normes Codex Alimentaires, Norme pour le thym séché. Adoptée en 2017 
Costa, N.R., Lourenço, J. and Pereira, Z.L. 2011. Desirability function approach: A review and performance evaluation in adverse conditions. Chemometrics and Intelligent Laboratory Systems 107(2):234244.

Han, W., Meng, Y., Hu, C., Dong, G., Qu, Y., Deng, H. and Guo, Y. 2017. Mathematical model of $\mathrm{Ca} 2+$ concentration, $\mathrm{pH}$, pectin concentration and soluble solids (sucrose) on the gelation of low methoxyl pectin. Food Hydrocolloids 66:37-48.

Lenth, R.V. 2009. Response-surface methods in $\mathrm{R}$, using rsm. Journal of Statistical Software 32(7):1-17.

Lin, S.-D., Sung, J.-M. and Chen, C.-L. 2011. Effect of drying and storage conditions on caffeic acid derivatives and total phenolics of Echinacea Purpurea grown in Taiwan. Food Chemistry 125(1):226-231.

Minolta, K. 2003. Precise color communication: Color control from perception to instrumentation. Konica Minolta Sensing, Inc.

Mishyna, M., Martinez, J.-J.I., Chen, J., Davidovich-Pinhas, M. and Benjamin, O. 2019. Heat-induced aggregation and gelation of proteins from edible honey bee brood (Apis mellifera) as a function of temperature and pH. Food Hydrocolloids 91:117-126.

Pathare, P., Opara, U.AndAl-Said, F. 2013. Colour measurement and analysis in fresh and processed foods: A review. Food and Bioprocess Technology 6:36-60.

Rahimmalek, M. and Goli, S.A.H. 2013. Evaluation of six drying treatments with respect to essential oil yield, composition and color characteristics of Thymys daenensis subsp. daenensis. Celak leaves. Industrial Crops and Products 42:613-619.

Rashford, J. 2018. The use of baobab leaves (Adansonia digitata L.) for food in Africa: A review. Economic Botany 72(4):478495.

Sathe, S.K. and Salunkhe, D.K. 1981. Functional properties of the great northern bean (Phaseolus vulgaris L.) proteins: Emulsion, foaming, viscosity, and gelation properties. Journal of Food Science 46(1):71-81.

Seremet, L., Botez, E., Nistor, O.-V., Andronoiu, D.G. and Mocanu, G.-D. 2016. Effect of different drying methods on moisture ratio and rehydration of pumpkin slices. Food Chemistry 195(1):104-109.

Soomro, S.A., Chen, K. and Soomro, S.A. 2020. Mathematical modelling and optimisation of low-temperature drying on quality aspects of rough rice. Journal of Food Quality 2020:1-10.

Yuliarti, O., Hoon, A.L.S. and Chong, S.Y. 2017. Influence of $\mathrm{pH}$, pectin and $\mathrm{Ca}$ concentration on gelation properties of lowmethoxyl pectin extracted from Cyclea barbata Miers. Food Structure 11:16-23. 